\title{
ANTHROPOLOGICAL CHARACTERISTIC OF THE HEAD AND FACE OF THE NATIVE PEOPLE FROM NORTH SULAWESI
}

\author{
Stanislav V. Drobyshevsky \\ Lomonosov Moscow State University, Moscow, Russian Federation \\ Ekaterina M. Selivanova \\ Lomonosov Moscow State University, Moscow, Russian Federation \\ Marina A. Negasheva \\ Lomonosov Moscow State University, Moscow, Russian Federation
}

\begin{abstract}
Introduction. The population of Indonesia is not well enough explored anthropologically. There are no reliable anthropometric data for some populations, living on Sulawesi Island. For the first time in scientific literature, a description of head and face traits of the indigenous populations of North Sulawesi, which remained completely anthropologically unexplored until now, is presented. Methods. The authors study the Minahasans $(n=96)$ and the Sangirese people ( $n=76)$ using the classical anthropometrical programme, including metrical $(n=14)$ and nonmetrical $(n=29)$ features. Analysis. The sudy of the Minahasans and the Sangirese people shows that these ethnic groups are generally similar; significant differences were found in a small number of traits. The Sangirese people have darker pigmentation of the skin and the iris than the Minahasans. More frequently they are wavy or even curly heared. In general, the population of North Sulawesi can be described as belonging to the South Asian population. However, the review of some traits of the Sangirese people and the Minahasans (hyperbrachycephalia, epicanthus occurs rather rare, narrow nose) put them on the borderline of variability of the explored South, Southeast Asian and Oceanian population. Sulawesi peoples (comparatively dark-skinned, sometimes curly haired) can presumably have equatorial mixture. Results. The Minahasans are close to the Dayak people of Kalimantan. The Sangirese people can have insignificant melanesian mixture because of their kinship with the Philippines people, perhaps with the Negrito of the Philippines. This conclusion is preliminary and has to be substantiated.

Key words: anthropology, morphological features, population of Indonesia, Sulawesi, Minahasans, Sangirese.

Citation. Drobyshevsky S.V., Selivanova E.M., Negasheva M.A. Anthropological Characteristic of the Head and Face of the Native People from North Sulawesi. Vestnik Volgogradskogo gosudarstvennogo universiteta. Seriya 4. Istoriya. Regionovedenie. Mezhdunarodnye otnosheniya [Science Journal of Volgograd State University. History. Area Studies. International Relations], 2020, vol. 25, no. 1, pp. 183-199. (in Russian). DOI: https://doi.org/10.15688/jvolsu4.2020.1.15

\section{АНТРОПОЛОГИЧЕСКАЯ ХАРАКТЕРИСТИКА СТРОЕНИЯ ГОЛОВЫ И ЛИЦА КОРЕННОГО НАСЕЛЕНИЯ СЕВЕРНОГО СУЛАВЕСИ}

\section{Станислав Владимирович Дробышевский}

Московский государственный университет им. М.В. Ломоносова, г. Москва, Российская Федерация

\section{Екатерина Максимовна Селиванова}

Московский государственный университет им. М.В. Ломоносова, г. Москва, Российская Федерация

\section{Марина Анатольевна Негашева}

Московский государственный университет им. М.В. Ломоносова, г. Москва, Российская Федерация 
Аннотация. Население Индонезии крайне мало изучено антропологически, по популяциям, проживающим на острове Сулавеси, до сих пор достоверных антропометрических данных не было вовсе. Впервые в научной литературе представлено описание признаков головы и лица коренного населения Северного Сулавеси, до настоящего времени остававшегося совершенно неисследованным антропологически. Минахасцы $(n=96)$ и сангирцы $(n=76)$ исследованы по классической программе, включавшей измерительные и описательные антропологические признаки. Два исследованных этноса Северного Сулавеси - минахасцы и сангирцы - по большинству морфологических признаков достоверно не отличаются, но обнаруживают достоверные отличия по ряду важных расоводиагностических признаков: сангирцы по сравнению с минахасцами обладают более темной пигментацией кожи и радужной оболочки глаз, чаще волнисто- и даже курчавоволосы. В целом население Северного Сулавеси может быть охарактеризовано как принадлежащее к южноазиатской расе. Вместе с тем комплекс признаков минахасцев и сангирцев (гипербрахикефалия, крайняя редкость эпикантуса, узкий нос) ставит их на край изменчивости исследованных популяций Южной, Юго-Восточной Азии и Океании. Некоторые черты населения Северного Сулавеси (сравнительная темнокожесть, присутствие в популяции индивидов с курчавыми волосами) могут быть предположительно истолкованы как свидетельство экваториальной примеси. Минахасцы могут иметь веддоидную примесь вследствие родства с даяками Калимантана; сангирцы могут обладать незначительной меланезоидной примесью вследствие родства с населением Филиппин, возможно - негрито. Этот вывод предварителен и нуждается в дальнейшем обосновании; для успешного решения вопроса необходимы дальнейшие исследования населения Индонезии. Вклад авторов. С.В. Дробышевский и Е.М. Селиванова рассмотрели литературу и предложили концепцию исследования. М.А. Негашева разработала дизайн и программу исследования. Е.М. Селиванова организовала экспедицию и осуществила измерения морфологических показателей строения головы и лица коренного населения Северного Сулавеси, а также сформировала базу антропометрических данных. С.В. Дробышевский, Е.М. Селиванова и М.А. Негашева провели статистический анализ и подготовили рукопись.

Ключевые слова: антропология, морфологические особенности, население Индонезии, Сулавеси, минахасцы, сангирцы.

Цитирование. Дробышевский С. В., Селиванова Е. М., Негашева М. А. Антропологическая характеристика строения головы и лица коренного населения Северного Сулавеси // Вестник Волгоградского государственного университета. Серия 4, История. Регионоведение. Международные отношения. - 2020. - Т. 25 , № 1. -C. 183-199. -DOI: https://doi.org/10.15688/jvolsu4.2020.1.15

Введение. Современное население Индонезии изучено крайне мало. По подавляющей части ее областей никаких достоверных данных нет. Вместе с тем Индонезия является чрезвычайно интересным в антропологическом отношении регионом. На ее территории пересекались разные варианты восточных экваториалов, монголоидов и, возможно, местных специфических рас. Предположительно на востоке Индонезии в плейстоцене происходила и метисация с денисовскими людьми [5]. История популяций, обитающих на множестве островов, колеблется между двумя противоположными тенденциями: с одной стороны, изоляция, вплоть до крайних случаев, с другой - повышенная мобильность, в том числе на огромные расстояния. Даже на первый взгляд популяции Индонезии крайне разнообразны. Все это делает изучение антропологии региона важным и актуальным.

Одним из центров разнообразия в пределах Индонезии является остров Сулавеси. Об антропологическом своеобразии его насе- ления много говорилось (например: [2]), однако достоверные числовые данные до настоящего времени практически полностью отсутствовали (единственная информация - измерение роста пяти минахасцев в 1905 году [22]).

Неоднократно предполагалось, что древнейшим населением региона было меланезоидное - темнокожее, курчавоволосое, прогнатное. После оно якобы было замещено веддоидным - менее темнокожим, волнистоволосым, менее прогнатным (в некоторых построениях эти две стадии заселения меняются местами). Третьей волной заселения считалась монголоидная - популяции со светлой кожей, прямыми волосами, уплощенным лицом. Население Сулавеси предполагалось как смешанное, в чертах коего отражаются процессы смешения разных волн заселения. Все подобные построения были основаны на общих соображениях, но не имели под собой фактических оснований, так как реальных исследований населения Сулавеси никогда не проводилось; население это упо- 
миналось и как веддоидное, и как монголоидное, и как специфическое.

Учитывая все сказанное, авторами была поставлена цель: дать антропологическую характеристику головы и лица современного населения Северного Сулавеси. В рамках этой цели были выделены следующие задачи: произвести описание морфологических особенностей лица и головы минахасцев и сангирцев; дать оценку однородности населения Северного Сулавеси; произвести сравнение исследованных групп населения Северного Сулавеси с населением окружающих регионов.

Достоверных данных об истории изученных народов немного. Минахасцы, с некоторой вероятностью, прибыли в результате нескольких волн миграций с севера [34], хотя, согласно их собственным преданиям, первые из них пришли по реке Раноиапо с юга. Важно, что Северный Сулавеси был достаточно изолированным, индийское влияние здесь было минимальным, исламизации тут не было.

Побережья островов севернее Сулавеси в некоторые моменты почти полностью лишались постоянного населения из-за постоянных набегов пиратов. Современное население появилось там лишь в XIX в. и, вероятно, тесно связано с филиппинцами, к которым близки и языки минахасцев и сангирцев [28]. Впрочем, в центральных областях островов люди, видимо, жили постоянно. Точные пути их изначальных миграций неизвестны.

Для выполнения задачи авторами статьи в июле - августе 2014 г. была организована антропологическая экспедиция на север острова Сулавеси.

Методы. Экспедиция проходила в окрестностях города Манадо, где исследовались минахасцы, и на острове Сангир (расположен среди цепочки островов, соединяющей Сулавеси с Филиппинами), где исследовались сангирцы.

В ходе экспедиции были измерены 96 минахасцев (из них 79 мужчин и 17 женщин) и 76 сангирцев (из них 63 мужчины и 13 женщин).

Все исследуемые являются коренными жителями Северного Сулавеси, то есть их предки до третьего поколения проживали на данной территории. Эта информация выяснялась с помощью анкетирования. С учетом правил биоэтики каждый исследуемый подписал информированное согласие об участии в антропологическом исследовании и обработке личных данных, специально для этих целей переведенное на индонезийский язык.

В данной статье приводятся данные о измерительных и описательных признаках головы и лица. Все измерения производились на месте, часть балловых признаков определялась по фотографиям.

Измерения проводились по стандартной антропометрической программе [1], включающей 14 размеров: длина тела, вес, продольный диаметр головы, поперечный диаметр головы, наименьшая ширина лба, скуловой диаметр, нижнечелюстной диаметр, физиономическая высота лица, морфологическая высота лица, высота носа, ширина носа, высота верхней губы, толщина губ и ширина рта. Описательная часть часть программы на месте включала: цвет кожи по шкале Лушана (баллы 1-9- очень светлые оттенки, 10-14 - светлые, 15-18 - средней окраски, 19-23 - темные, 24-35 - очень темные), цвет волос по шкале Фишера-Заллера (1-3 - рыжие, 4 - черно-каштановые, 5-7 - каштановые, 8 - темно-белокурые, 9-20 - светло-белокурые, 2226 - пепельные, 27 - черные), цвет радужной оболочки глаз по шкале Бунака (1 - черный, 2 - темно-карий с равномерной окраской радужины, 3 - светло-карий с неравномерной в разных участках окраской радужины, 4 - желтый, 5 - буро-желто-зеленый, 6 - зеленый, 7 серо-зеленый, 8 - серый или голубой с бурожелтым венчиком вокруг зрачка, 9 - серый различных оттенков, 10 - серо-голубой с хорошо выраженным рисунком, 11 - голубой с рисунком в виде полосок, 12 - основной фон синий, без рисунка), форма волос и волосяной покров на груди. По фотографиям, сделанным в трех нормах, определялись 24 описательных признака: рост бороды, рост бровей, ширина и наклон глазной щели, развитие эпикантуса, складка верхнего века, наклон лба, развитие надбровья, профиль лица, развитие скул, выступание подбородка, высота переносья, поперечный профиль спинки носа, костный, хрящевой и общий профили спинки носа, положение основания носа, положение кончика носа, высота крыльев носа, выступание крыльев носа, высота верхней губы, выступание верхней 
губы, толщина верхней губы, толщина нижней губы.

Всеполученные данные по измерительным и описательным признакам обрабатывались с помощью пакета программ STATISTICA. Для измерительных признаков были рассчитаны средние величины, стандартные отклонения и коэффициент вариации. Для балловых признаков были рассчитаны средние величины и частота встречаемости в популяции каждого варианта признака.

\section{Анализ: минахасцев. \\ 1. Внутригрупповая изменчивость}

Наибольшими коэффициентами вариации среди измеренных признаков обладают вес, высота верхней губы и толщина обеих губ (табл. 1). Это можно объяснять погрешностью измерений, так как многие участники исследования во время измерения данного размера с трудом сдерживают улыбку, что могло сказаться на результатах. Все остальные коэффициенты вариации соответствуют ожидаемым величинам для размеров лица.

Наибольшим стандартным отклонением из всех измеренных размеров лица обладает физиономическая высота лица. Это может быть связано с большим размахом изменчивости данного размера среди минахасцев. Разница между минимальным и максимальным значениями этого признака составляет 56 мм.

Малая численность женской части выборки не позволяет говорить о достоверности полученных коэффициентов, но повышенными значениями коэффициента вариации по сравнению с ожидаемыми по-прежнему обладают размеры губ (табл. 2).

Для мужчин минахасцев характерен очень слабый рост бороды и слабый рост бровей (табл. 3). У большинства минахасцев отсутствует эпикантус; он наличествует лишь у $17,11 \%$ мужчин и $13,33 \%$ женщин, причем часто только на правом глазу (асимметрия, впрочем, не достоверна). Минахасцы характеризуются слабым развитием надбровья, убегающим подбородком, прямой спинкой носа, приподнятым положением основания носа и прохейлией.

Цвет кожи, определенный по шкале Лушана, среди минахасцев преобладает свет- лый: № 10-14-81,25 \%; среднеокрашенный $12,5 \%$; очень светлый редок $-6,25 \%$.

Цвет глаз, определенный по шкале Бунака, среди минахасцев преобладает темный: цвет $1-57,29 \%$, а сумма цветов 1,2 и $3-$ $98,96 \%$.

Цвет волос, определенный по шкале Фишера-Заллера, у всех измеренных представителей популяции минахасцев черный $(Y)$.

Форма волос у 96,875 \% минахасцев прямая, у 3,125 \% - волнистая. Курчавая форма волос среди исследованных минахасцев не встретилась.

\section{2. Внутригрупповая изменчивость сангирцев. \\ Наибольшими коэффициентами вариации} в мужской части популяции сангирцев со значениями $19,69,16,61$ и 13,97 , как и в случае с выборкой минахасцев, обладают, соответственно, масса тела, толщина обеих губ и высота верхней губы (табл. 4).

В женской части выборки наибольшими коэффициентами вариации также обладают вес, высота верхней губы и толщина обеих губ с соответствующими значениями $21,04,24,31$ и 20,9 (табл. 5).

Среди оттенков кожи по шкале Лушана у сангирцев преобладают светлые: № 10-14 73,69 \%, а среди них - № 13 и 14 (табл. 6).

В изученной популяции сангирцев встречается только темный - 1 и 2 - цвет радужной оболочки глаза по шкале Бунака с соответствующими частотами 52,63 и 47,37 \%.

У сангирцев чаще всего встречается прямая форма волос, однако есть индивиды с волнистыми и даже курчавыми волосами.

3. Сравнение изученных популяций минахасцев и сангирцев.

Для анализа достоверности различий частот встречаемости балловых признаков использовался пакет программ STATISTICA, а именно Difference Test.

Достоверные различия выявлены для частот встречаемости оттенков кожи 10 и 18: оттенок 10 достоверно чаще встречается у минахасцев, тогда как 18 - у сангирцев (табл. 7). В сумме сангирцы могут быть охарактеризованы как несколько более темнопигментированные; хотя по прочим оттенкам отличия недостоверны, они явно проявляют ту же тенденцию. 
У сангирцев достоверно чаще встречается самый темный цвет глаз по шкале Бунака (табл. 8) и волнистая форма волос, у минахасцев - прямая форма волос (табл. 9).

Для описательных признаков, определенных по фотографиям, выявлены достоверные различия в частоте встречаемости балла 3 медиальной и дистальной частей складки верхнего века: у минахасцев достоверно чаще встречаются крайние варианты развития этих признаков (табл. 10). Также, у минахасцев достоверно чаще встречается выпуклая форма хрящевого профиля спинки носа, а у сангирцев прямая форма этого же признака, но достоверных различий в общем профиле спинки носа не выявлено. И, наконец, у сангирцев достоверно чаще встречается средняя высота верхней губы.

Достоверные различия балловых признаков в изученных популяциях сангирцев и минахасцев крайне малочисленны, и, судя по различающимся признакам, имеют случайный характер.

В целом популяции сангирцев и минахасцев почти не отличаются по использованным в работе балловым признакам лица и головы. Однако сангирцы по сравнению с минахасцами обладают более темной пигментацией кожи и радужной оболочки глаз, чаще волнисто- и даже курчавоволосы. Такие различия могут быть связаны с тем, что сангирцы имеют более тесную связь с филиппинцами, так как они проживают на границе Индонезии с Филиппинами. Минахасцы же больше связаны с жителями острова Калимантан, так как большинство трудоспособных мужчин минахасцев в течение года работает в промышленных районах острова Калимантан.

Одномерный дисперсионный анализ ANOVA, проведенный в пакете программ STATISTICA, дал в целом аналогичные результаты (табл. 11).

У женщин достоверные различия были выявлены только для цвета кожи со значением $F$-критерия Фишера 8,923 и вероятностью ошибки первого рода 0,006 .

В целом минахасцы и сангирцы могут быть охарактеризованы как представители южноазиатской расы. Голова гипербрахикефальная; лицо низкое и широкое, умеренно уплощенное (измерений нет), эпикантус редок, а при наличии всегда выражен слабо, волосы и глаза всегда темные, кожа светлая, нос узкий, губы прохейличные, толще средних, но не толстые.

Положение исследованных групп среди населения окружающих регионов установимо с трудом, так как сравнимых данных крайне недостаточно [3; 4; 6-27; 29-33; 35]. Фактически в мало-мальски достаточном количестве групп сравнимы лишь головной и носовой указатели. По обоим сангирцы и минахасцы, будучи мезоринными гипербрахикефалами, находятся к крайних пределах изменчивости населения Индонезии, Меланезии и Полинезии, а по сочетанию двух указателей - занимают крайнее положение. Схожие значения носового указателя встречены только у корейцев, даяков моря и суши, малайцев, метисов Кисара и японцев, а головного - у корейцев, японцев, филиппинских илоков и бисайя, гавайцев и таитян. Все меланезийцы, равно как малайские и филиппинские негрито, западные полинезийцы и микронезийцы, резко отличаются от сангирцев и минахасцев.

Круг наиболее близких популяций включает корейцев и японцев, даяков моря и малайцев, таитян. Похожи, но более широконосы илоки и бисайя, хотя другие филиппинские группы - игорот, биколь, тагалоги, ибанаги, пампанган - ближе к меланезийцам (даже китайцы хакка чуть больше похожи на сангирцев и минахасцев).

Сходство с корейцами и японцами по головному и носовому указателям сопровождается заметным отличием по высоте лица и лицевому указателю, толщине губ (у японцев толще), а также резким - по частоте эпикантуса.

Сближение с популяциями Филиппин вполне закономерно, так как между Северным Сулавеси и Филиппинами существуют давние и тесные связи. Сангирцы, будучи в среднем чуть долихокефальнее, едва уловимо ближе к филиппинцам, чем минахасцы, хотя эти различия недостоверны; географически эта тенденция вполне логична.

Сходство с малайцами и даяками моря, вероятно, отражает общее происхождение. Наличие курчавых волос среди сангирцев, их большая волнистоволосость и темнокожесть могут быть интерпретированы как доказа- 


\section{НАРОДЫ МИРА: АРХЕОЛОГИЯ, АНТРОПОЛОГИЯ, ИСТОРИЯ}

тельство небольшой веддоидной или меланезоидной примеси. Меланезоидная (в узком смысле) примесь маловероятна, так как все группы Меланезии отличаются от сангирцев слишком сильно. Возможно, впрочем, отдаленное непрямое влияние филиппинских негрито. С другой стороны, на рядом расположенном Калимантане, где работает большинство мужчин минахасцев, проживают даяки суши - веддоиды, а также даяки моря, имеющие, вероятно, тоже немалую веддоидную примесь.

Результаты. Два исследованных этноса Северного Сулавеси - минахасцы и сангирцы - по большинству морфологических признаков достоверно не отличаются, но обнаруживают расхождение по ряду важных ра- соводиагностических признаков: сангирцы имеют более темную пигментацию кожи и глаз, чаще волнисто- и курчавоволосы.

Население Северного Сулавеси занимает крайнее положение среди исследованных групп малайско-индонезийского региона: уклоняются в сторону монголоидных групп, в том числе не близких географически, и отличаются от меланезоидных и веддоидных групп региона.

Минахасцы могут иметь веддоидную примесь вследствие родства с населением Калимантана; сангирцы могут обладать незначительной меланезоидной примесью вследствие родства с населением Филиппин. Этот вывод предварителен и нуждается в дальнейшем обосновании. 


\section{ПРИЛОЖЕНИЕ}

\section{Таблица 1. Антропометрическая характеристика мужчин минахасцев}

Table 1. Anthropometric characteristics of Minahasan men

\begin{tabular}{|l|c|c|c|c|c|c|}
\hline \multicolumn{1}{|c|}{ Признаки } & $N$ & $\begin{array}{c}\text { Ми- } \\
\text { нимум }\end{array}$ & $\begin{array}{c}\text { Мак- } \\
\text { симум }\end{array}$ & $\begin{array}{c}\text { Среднее } \\
\text { значение }\end{array}$ & $\begin{array}{c}\text { Стандартное } \\
\text { отклонение }\end{array}$ & $\begin{array}{c}\text { Коэффициент } \\
\text { вариации }\end{array}$ \\
\hline Вес (кг) & 79 & 42 & 137 & 68,30 & 14,73 & 21,56 \\
\hline Рост (мм) & 79 & 1558 & 1806 & 1666,95 & 61,47 & 3,69 \\
\hline Продольный диаметр головы (мм) & 78 & 173 & 197 & 186,01 & 5,45 & 2,93 \\
\hline Поперечный диаметр головы (мм) & 78 & 149 & 172 & 159,74 & 5,21 & 3,26 \\
\hline Лобный диаметр (мм) & 78 & 97 & 131 & 110,17 & 6,07 & 5,51 \\
\hline Скуловой диаметр (мм) & 78 & 130 & 157 & 146,69 & 5,21 & 3,55 \\
\hline Нижнечелюстной диаметр (мм) & 78 & 97 & 126 & 109,73 & 6,56 & 5,98 \\
\hline Физиономическая высота лица (мм) & 79 & 174 & 230 & 193,35 & 10,59 & 5,48 \\
\hline Морфологическая высота лица (мм) & 79 & 112 & 149 & 129,03 & 7,73 & 5,99 \\
\hline Высота носа (мм) & 79 & 47 & 74 & 59,72 & 4,84 & 8,10 \\
\hline Высота верхней губы (мм) & 79 & 8 & 21 & 14,81 & 2,84 & 19,19 \\
\hline Толщина обеих губ (мм) & 79 & 10 & 26 & 18,34 & 3,29 & 17,93 \\
\hline Ширина носа (мм) & 79 & 32 & 59 & 39,77 & 3,68 & 9,25 \\
\hline Ширина рта (мм) & 79 & 41 & 62 & 50,73 & 4,04 & 7,96 \\
\hline
\end{tabular}

\section{Таблица 2. Антропометрическая характеристика женщин минахасцев}

\section{Table 2. Anthropometric characteristics of Minahasan women}

\begin{tabular}{|l|c|c|c|c|c|c|}
\hline \multicolumn{1}{|c|}{ Признаки } & $N$ & $\begin{array}{c}\text { Ми- } \\
\text { нимум }\end{array}$ & $\begin{array}{c}\text { Мак- } \\
\text { симум }\end{array}$ & $\begin{array}{c}\text { Среднее } \\
\text { значение }\end{array}$ & $\begin{array}{c}\text { Стандартное } \\
\text { отклонение }\end{array}$ & $\begin{array}{c}\text { Коэффициент } \\
\text { вариации }\end{array}$ \\
\hline Вес (кг) & 17 & 40 & 87 & 57,06 & 13,40 & 23,49 \\
\hline Рост (мм) & 17 & 1462 & 1662 & 1548,41 & 53,13 & 3,43 \\
\hline Продольный диаметр головы (мм) & 17 & 169 & 188 & 176,88 & 5,43 & 3,07 \\
\hline Поперечный диаметр головы (мм) & 17 & 142 & 159 & 152,00 & 5,80 & 3,81 \\
\hline Лобный диаметр (мм) & 17 & 93 & 117 & 107,12 & 5,73 & 5,35 \\
\hline Скуловой диаметр (мм) & 17 & 114 & 148 & 137,82 & 7,58 & 5,50 \\
\hline Нижнечелюстной диаметр (мм) & 17 & 96 & 112 & 104,94 & 5,07 & 4,83 \\
\hline Физиономическая высота лица (мм) & 17 & 161 & 205 & 180,76 & 11,75 & 6,50 \\
\hline Морфологическая высота лица (мм) & 17 & 105 & 131 & 119,35 & 7,58 & 6,35 \\
\hline Высота носа (мм) & 17 & 51 & 70 & 58,24 & 5,48 & 9,42 \\
\hline Высота верхней губы (мм) & 17 & 9 & 17 & 12,82 & 2,30 & 17,92 \\
\hline Толщина обеих губ (мм) & 17 & 11 & 22 & 17,88 & 2,89 & 16,17 \\
\hline Ширина носа (мм) & 17 & 32 & 47 & 37,12 & 3,95 & 10,64 \\
\hline Ширина рта (мм) & 17 & 41 & 59 & 47,65 & 4,36 & 9,15 \\
\hline
\end{tabular}


НАРОДЫ МИРА: АРХЕОЛОГИЯ, АНТРОПОЛОГИЯ, ИСТОРИЯ

Таблица 3. Средние значения и частоты встречаемости баллов описательных признаков в популяции минахасцев

Table 3. Average values and frequency of occurrence of descriptive traits scores in the Minahasan population

\begin{tabular}{|c|c|c|c|c|c|c|}
\hline \multirow[b]{2}{*}{ Признаки } & \multirow[b]{2}{*}{$N$} & \multicolumn{2}{|c|}{ Мужчины } & \multirow[b]{2}{*}{$N$} & \multicolumn{2}{|c|}{ Женщины } \\
\hline & & $\begin{array}{c}\text { частота встре- } \\
\text { чаемости, \% }\end{array}$ & $\begin{array}{c}\text { средний } \\
\text { балл }\end{array}$ & & $\begin{array}{c}\text { частота встре- } \\
\text { чаемости, \% }\end{array}$ & $\begin{array}{c}\text { средний } \\
\text { балл }\end{array}$ \\
\hline Pост бороды & \multirow{7}{*}{76} & & \multirow{7}{*}{1,43} & \multirow{7}{*}{17} & & \multirow{7}{*}{0,00} \\
\hline отсутствует (0) & & 1,32 & & & 100,00 & \\
\hline очень слабый (1) & & 61,84 & & & 0,00 & \\
\hline слабый (2) & & 28,95 & & & 0,00 & \\
\hline средний (3) & & 7,89 & & & 0,00 & \\
\hline сильный (4) & & 0,00 & & & 0,00 & \\
\hline очень сильный (5) & & 0,00 & & & 0,00 & \\
\hline Рост бровей & \multirow{4}{*}{76} & & \multirow{4}{*}{1,45} & \multirow{4}{*}{14} & & \multirow{4}{*}{1,22} \\
\hline слабый (1) & & 56,58 & & & 78,57 & \\
\hline средний (2) & & 42,10 & & & 27,27 & \\
\hline сильный (3) & & 1,32 & & & 0,00 & \\
\hline Ширина глазной щели & \multirow{4}{*}{76} & & \multirow{4}{*}{1,75} & \multirow{4}{*}{15} & & \multirow{4}{*}{1,83} \\
\hline узкая (1) & & 26,32 & & & 20,00 & \\
\hline средняя (2) & & 73,68 & & & 80,00 & \\
\hline широкая (3) & & 0,00 & & & 0,00 & \\
\hline Наклон глазной щеели & \multirow{4}{*}{74} & & \multirow{4}{*}{2,05} & \multirow{4}{*}{15} & & \multirow{4}{*}{2,47} \\
\hline внутренний угол выше наружного (1) & & 0,00 & & & 0,00 & \\
\hline горизонтальное положение (2) & & 94,59 & & & 53,33 & \\
\hline наружный угол выше внутреннего (3) & & 5,41 & & & 46,67 & \\
\hline Развитие эпикантуса & & & & & & \\
\hline отсутствует $(0)$ & & 82,89 & & & 86,67 & \\
\hline слабое развитие (1) & 76 & 17,11 & 0,17 & 15 & 13,33 & 0,13 \\
\hline среднее развитие (2) & & 0,00 & & & 0,00 & \\
\hline сильное развитие (3) & & 0,00 & & & 0,00 & \\
\hline Складка верхнего века & & & & & & \\
\hline проксимальная часть & & & & & & \\
\hline отсутствует $(0)$ & & 1,32 & & & 0,00 & \\
\hline слабое развитие (1) & 76 & 3,95 & 2,00 & 15 & 6,67 & 1,93 \\
\hline среднее развитие (2) & & 90,78 & & & 93,33 & \\
\hline сильное развитие (3) & & 3,95 & & & 0,00 & \\
\hline медиальная часть & & & & & & \\
\hline отсутствует (0) & & 1,32 & & & 0,00 & \\
\hline слабое развитие (1) & 76 & 3,95 & 2,15 & 15 & 6,67 & 2,07 \\
\hline среднее развитие (2) & & 74,99 & & & 80,00 & \\
\hline сильное развитие (3) & & 19,74 & & & 13,33 & \\
\hline дистальная часть & & & & & & \\
\hline Отсутствует (0) & & 1,32 & & & 0,00 & \\
\hline слабое развитие (1) & 76 & 3,95 & 2,11 & 15 & 0,00 & 2,20 \\
\hline среднее развитие (2) & & 78,94 & & & 80,00 & \\
\hline сильное развитие (3) & & 15,79 & & & 20,00 & \\
\hline Наклон лба & & & & & & \\
\hline сильно покатый (1) & 74 & 0,00 & 242 & 14 & 0,00 & 238 \\
\hline средне покатый (2) & 74 & 55,26 & 2,43 & 14 & 66,67 & 2,38 \\
\hline прямой (3) & & 44,74 & & & 33,33 & \\
\hline Развитие надбровья & & & & & & \\
\hline слабое развитие (1) & 74 & 72,37 & 126 & 14 & 100,00 & \\
\hline среднее развитие (2) & 74 & 27,63 & 1,26 & 14 & 0,00 & 1,00 \\
\hline сильное развитие (3) & & 0,00 & & & 0,00 & \\
\hline
\end{tabular}


Продолжение таблицы 3

Continuation of table 3

\begin{tabular}{|c|c|c|c|c|c|c|}
\hline \multirow[b]{2}{*}{ Признаки } & \multirow[b]{2}{*}{$N$} & \multicolumn{2}{|c|}{ Мужчины } & \multirow[b]{2}{*}{$N$} & \multicolumn{2}{|c|}{ Женщины } \\
\hline & & $\begin{array}{c}\text { частота встре- } \\
\text { чаемости, \% }\end{array}$ & $\begin{array}{c}\text { средний } \\
\text { балл }\end{array}$ & & $\begin{array}{c}\text { частота встре- } \\
\text { чаемости, \% }\end{array}$ & $\begin{array}{c}\text { средний } \\
\text { балл }\end{array}$ \\
\hline Профиль лица & \multirow{4}{*}{75} & & \multirow{4}{*}{1,73} & \multirow{4}{*}{15} & & \multirow{4}{*}{1,53} \\
\hline плоское (1) & & 26,32 & & & 46,67 & \\
\hline среднее (2) & & 73,68 & & & 53,33 & \\
\hline узкое (3) & & 0,00 & & & 0,00 & \\
\hline Развитие скул & \multirow{4}{*}{75} & & \multirow{4}{*}{1,83} & \multirow{4}{*}{15} & & \multirow{4}{*}{2,13} \\
\hline слабое развитие (1) & & 17,11 & & & 6,67 & \\
\hline среднее развитие (2) & & 82,89 & & & 73,33 & \\
\hline сильное развитие (3) & & 0,00 & & & 20,00 & \\
\hline Bыступание подбородка & \multirow{4}{*}{75} & & \multirow{4}{*}{1,25} & \multirow{4}{*}{15} & & \multirow{4}{*}{1,40} \\
\hline убегающий (1) & & 73,68 & & & 60,00 & \\
\hline прямой (2) & & 26,32 & & & 40,00 & \\
\hline выступающий (3) & & 0,00 & & & 0,00 & \\
\hline Высота переносья & \multirow{4}{*}{75} & & \multirow{4}{*}{1,49} & \multirow{4}{*}{15} & & \\
\hline низкое (1) & & 52,00 & & & 60,00 & \\
\hline среднее (2) & & 48,00 & & & 40,00 & 1,40 \\
\hline высокое (3) & & 0,00 & & & 0,00 & \\
\hline Поперечный профиль спинки носа & & & & & & \\
\hline плоский (1) & & 13,16 & & 15 & 33,33 & \\
\hline средний (2) & 75 & 86,84 & 1,87 & 15 & 66,67 & 1,67 \\
\hline заостренный (3) & & 0,00 & & & 0,00 & \\
\hline Костный профиль спинки носа & & & & & & \\
\hline вогнутый (1) & 75 & 0,00 & 201 & 15 & 6,67 & 103 \\
\hline прямой (2) & 75 & 98,67 & 2,01 & 15 & 93,33 & 1,93 \\
\hline выгнутый (3) & & 1,33 & & & 0,00 & \\
\hline Хрящевой профиль спинки носа & & & & & & \\
\hline вогнутый (1) & & 4,00 & & & 13,33 & \\
\hline прямой (2) & 75 & 85,33 & 2,07 & 15 & 86,67 & 1,87 \\
\hline выгнутый (3) & & 10,67 & & & 0,00 & \\
\hline Общчий профиль спинки носа & & & & & & \\
\hline вогнутый (1) & & 4,00 & & & 20,00 & \\
\hline прямой (2) & 75 & 84,00 & 2,08 & 15 & 80,00 & 1,80 \\
\hline выгнутый (3) & & 12,00 & & & 0,00 & \\
\hline извилистый (4) & & 0,00 & & & 0,00 & \\
\hline Положение основания носа & & & & & & \\
\hline приподнятое (1) & 75 & 61,33 & 139 & 15 & 60,00 & 140 \\
\hline горизонтальное (2) & 75 & 38,67 & 1,39 & 15 & 40,00 & 1,40 \\
\hline опущенное (3) & & 0,00 & & & 0,00 & \\
\hline Положение кончика носа & & & & & & \\
\hline приподнятое (1) & 75 & 8,00 & $10 ?$ & 15 & 26,67 & 173 \\
\hline горизонтальное (2) & 75 & 92,00 & 1,92 & 15 & 73,33 & 1,73 \\
\hline опущенное (3) & & 0,00 & & & 0,00 & \\
\hline Выссота крыльев носа & & & & & & \\
\hline низкая (1) & & 12,16 & & & 46,67 & \\
\hline средняя (2) & 74 & 63,52 & 2,14 & 15 & 40,00 & 1,67 \\
\hline высокая (3) & & 24,32 & & & 13,33 & \\
\hline Выступание крыльев носа & & & & & & \\
\hline слабое (1) & 74 & 30,26 & & 15 & 20,00 & 180 \\
\hline среднее (2) & 74 & 68,42 & 1,70 & 15 & 80,00 & 1,80 \\
\hline сильное (3) & & 1,32 & & & 0,00 & \\
\hline
\end{tabular}


Окончание таблицы 3

End of table 3

\begin{tabular}{|c|c|c|c|c|c|c|}
\hline \multirow[b]{2}{*}{ Признаки } & \multirow[b]{2}{*}{$N$} & \multicolumn{2}{|c|}{ Мужчины } & \multirow[b]{2}{*}{$N$} & \multicolumn{2}{|c|}{ Женщины } \\
\hline & & $\begin{array}{c}\text { частота встре- } \\
\text { чаемости, \% }\end{array}$ & $\begin{array}{c}\text { средний } \\
\text { балл } \\
\end{array}$ & & $\begin{array}{c}\text { частота встре- } \\
\text { чаемости, \% }\end{array}$ & $\begin{array}{c}\text { средний } \\
\text { балл } \\
\end{array}$ \\
\hline Высота верхней губы & \multirow{4}{*}{76} & & \multirow{4}{*}{1,88} & \multirow{4}{*}{15} & & \multirow{4}{*}{1,67} \\
\hline низкая (1) & & 17,11 & & & 33,33 & \\
\hline средняя (2) & & 77,63 & & & 66,67 & \\
\hline высокая (3) & & 5,26 & & & 0,00 & \\
\hline Профиль верхней губь & \multirow{4}{*}{75} & & \multirow{4}{*}{1,33} & \multirow{4}{*}{15} & & \multirow{4}{*}{1,27} \\
\hline прохейлия (1) & & 66,67 & & & 73,33 & \\
\hline ортохейлия (2) & & 33,33 & & & 26,67 & \\
\hline опистохейлия (3) & & 0,00 & & & 0,00 & \\
\hline Толщиина верхней губы & \multirow{4}{*}{76} & & \multirow{4}{*}{1,69} & \multirow{4}{*}{15} & & \multirow{4}{*}{1,60} \\
\hline тонкая (1) & & 36,84 & & & 40,00 & \\
\hline средняя (2) & & 57,90 & & & 60,00 & \\
\hline толстая (3) & & 5,26 & & & 0,00 & \\
\hline Толщина нижней губы & \multirow{4}{*}{76} & & \multirow{4}{*}{2,20} & \multirow{4}{*}{15} & & \multirow{4}{*}{1,93} \\
\hline тонкая (1) & & 9,21 & & & 13,33 & \\
\hline средняя (2) & & 61,84 & & & 80,00 & \\
\hline толстая (3) & & 28,95 & & & 6,67 & \\
\hline
\end{tabular}

\section{Таблица 4. Антропометрическая характеристика мужчин сангирцев}

Table 4. Anthropometric characteristics of Sangirese men

\begin{tabular}{|l|c|c|c|c|c|c|}
\hline \multicolumn{1}{|c|}{ Признаки } & $N$ & $\begin{array}{c}\text { Мини- } \\
\text { мум }\end{array}$ & $\begin{array}{c}\text { Макси- } \\
\text { мум }\end{array}$ & $\begin{array}{c}\text { Среднее } \\
\text { значение }\end{array}$ & $\begin{array}{c}\text { Стандартное } \\
\text { отклонение }\end{array}$ & $\begin{array}{c}\text { Коэффициент } \\
\text { вариации }\end{array}$ \\
\hline Вес (кг) & 63 & 40 & 95 & 62,24 & 12,26 & 19,69 \\
\hline Рост (мм) & 63 & 1540 & 1774 & 1660,97 & 59,21 & 3,56 \\
\hline Продольный диаметр головы (мм) & 63 & 174 & 207 & 185,37 & 7,36 & 3,97 \\
\hline Поперечный диаметр головы (мм) & 63 & 140 & 170 & 158,03 & 6,10 & 3,86 \\
\hline Лобный диаметр (мм) & 63 & 85 & 131 & 108,17 & 6,30 & 5,83 \\
\hline Скуловой диаметр (мм) & 63 & 133 & 158 & 145,49 & 5,27 & 3,62 \\
\hline Нижнечелюстной диаметр (мм) & 63 & 94 & 124 & 107,62 & 6,13 & 5,70 \\
\hline Физиономическая высота лица (мм) & 63 & 176 & 210 & 195,86 & 7,99 & 4,08 \\
\hline Морфологическая высота лица (мм) & 63 & 113 & 147 & 130,62 & 7,25 & 5,55 \\
\hline Высота носа (мм) & 63 & 50 & 73 & 59,90 & 4,28 & 7,14 \\
\hline Высота верхней губы (мм) & 63 & 10 & 19 & 14,41 & 2,01 & 13,97 \\
\hline Толщина обеих губ (мм) & 62 & 10 & 25 & 18,39 & 3,05 & 16,61 \\
\hline Ширина носа (мм) & 63 & 32 & 47 & 39,83 & 3,23 & 8,10 \\
\hline Ширина рта (мм) & 63 & 42 & 60 & 50,40 & 3,86 & 7,66 \\
\hline
\end{tabular}

\section{Таблица 5. Антропометрическая характеристика женщин сангирцев}

\section{Table 5. Anthropometric characteristics of Sangirese women}

\begin{tabular}{|l|c|c|c|c|c|c|}
\hline \multicolumn{1}{|c|}{ Признаки } & $N$ & $\begin{array}{c}\text { Мини- } \\
\text { мум }\end{array}$ & $\begin{array}{c}\text { Макси- } \\
\text { мум }\end{array}$ & $\begin{array}{c}\text { Среднее } \\
\text { значение }\end{array}$ & $\begin{array}{c}\text { Стандартное } \\
\text { отклонение }\end{array}$ & $\begin{array}{c}\text { Коэффициент } \\
\text { вариации }\end{array}$ \\
\hline Вес (кг) & 13 & 47 & 90 & 59,62 & 12,54 & 21,04 \\
\hline Рост (мм) & 13 & 1417 & 1613 & 1511,62 & 51,70 & 3,42 \\
\hline Продольный диаметр головы (мм) & 13 & 164 & 183 & 173,77 & 5,17 & 2,97 \\
\hline Поперечный диаметр головы (мм) & 13 & 141 & 158 & 149,69 & 5,23 & 3,50 \\
\hline Лобный диаметр (мм) & 13 & 99 & 117 & 106,31 & 5,54 & 5,21 \\
\hline Скуловой диаметр (мм) & 13 & 126 & 145 & 135,62 & 5,64 & 4,16 \\
\hline Нижнечелюстной диаметр (мм) & 13 & 89 & 112 & 101,62 & 6,92 & 6,81 \\
\hline Физиономическая высота лица (мм) & 13 & 165 & 194 & 180,62 & 8,18 & 4,53 \\
\hline Морфологическая высота лица (мм) & 13 & 105 & 128 & 117,77 & 6,93 & 5,88 \\
\hline Высота носа (мм) & 13 & 51 & 70 & 57,69 & 4,75 & 8,23 \\
\hline Высота верхней губы (мм) & 13 & 8 & 20 & 13,38 & 3,25 & 24,31 \\
\hline Толщина обеих губ (мм) & 13 & 9 & 20 & 15,77 & 3,30 & 20,90 \\
\hline Ширина носа (мм) & 13 & 31 & 43 & 37,69 & 3,17 & 8,42 \\
\hline Ширина рта (мм) & 13 & 42 & 53 & 48,46 & 2,88 & 5,93 \\
\hline
\end{tabular}


Таблица 6. Средние значения и частоты встречаемости баллов описательных признаков в популяции сангирцев

Table 6. Average values and frequency of occurrence of descriptive traits scores in the Sangirese population

\begin{tabular}{|c|c|c|c|c|c|c|}
\hline \multirow[b]{2}{*}{ Признаки } & \multirow[b]{2}{*}{$N$} & \multicolumn{2}{|c|}{ Мужчины } & \multirow[b]{2}{*}{$N$} & \multicolumn{2}{|c|}{ Женщины } \\
\hline & & $\begin{array}{c}\text { частота встре- } \\
\text { чаемости, \% }\end{array}$ & $\begin{array}{c}\text { средний } \\
\text { балл }\end{array}$ & & $\begin{array}{c}\text { частота встре- } \\
\text { чаемости, \% }\end{array}$ & $\begin{array}{c}\text { средний } \\
\text { балл }\end{array}$ \\
\hline Poст бороды & \multirow{7}{*}{62} & & \multirow{7}{*}{1,40} & \multirow{7}{*}{13} & & \multirow{7}{*}{0,00} \\
\hline отсутствует $(0)$ & & 0,00 & & & 100,00 & \\
\hline очень слабый (1) & & 69,35 & & & 0,00 & \\
\hline слабый (2) & & 14,52 & & & 0,00 & \\
\hline средний (3) & & 16,13 & & & 0,00 & \\
\hline сильный (4) & & 0,00 & & & 0,00 & \\
\hline очень сильный (5) & & 0,00 & & & 0,00 & \\
\hline Рост бровей & \multirow{4}{*}{61} & & \multirow{4}{*}{1,67} & \multirow{4}{*}{13} & & \multirow{4}{*}{1,23} \\
\hline слабый (1) & & 32,79 & & & 76,92 & \\
\hline средний (2) & & 67,21 & & & 23,08 & \\
\hline сильный (3) & & 0,00 & & & 0,00 & \\
\hline Ширина глазной щзели & \multirow{4}{*}{62} & & \multirow{4}{*}{1,71} & \multirow{4}{*}{13} & & \multirow{4}{*}{1,77} \\
\hline узкая (1) & & 29,03 & & & 23,08 & \\
\hline средняя (2) & & 70,97 & & & 76,92 & \\
\hline широкая (3) & & 0,00 & & & 0,00 & \\
\hline Наклон глазной щеели & \multirow{4}{*}{62} & & \multirow{4}{*}{2,05} & \multirow{4}{*}{13} & & \multirow{4}{*}{2,23} \\
\hline внутренний угол выше наружного (1) & & 0,00 & & & 7,69 & \\
\hline горизонтальное положение (2) & & 95,16 & & & 61,54 & \\
\hline наружный угол выше внутреннего (3) & & 4,84 & & & 30,77 & \\
\hline Развитие эпикантуса & & & & & & \\
\hline отсутствует $(0)$ & & 87,10 & & & 92,31 & \\
\hline слабое развитие (1) & 62 & 12,90 & 0,13 & 13 & 7,69 & 0,08 \\
\hline среднее развитие (2) & & 0,00 & & & 0,00 & \\
\hline сильное развитие (3) & & 0,00 & & & 0,00 & \\
\hline Складка верхнего века & & & & & & \\
\hline проксимальная часть & & & & & & \\
\hline отсутствует (0) & 62 & 0,00 & 105 & 13 & 0,00 & 102 \\
\hline слабое развитие (1) & 62 & 8,06 & 1,95 & 13 & 7,69 & 1,92 \\
\hline среднее развитие (2) & & 88,71 & & & 92,31 & \\
\hline сильное развитие (3) & & 3,23 & & & 0,00 & \\
\hline медиальная часть & & & & & & \\
\hline отсутствует (0) & & 0,00 & & & 0,00 & \\
\hline слабое развитие (1) & 62 & 6,45 & 2,00 & 13 & 7,69 & 2,08 \\
\hline среднее развитие (2) & & 87,10 & & & 76,92 & \\
\hline сильное развитие (3) & & 6,45 & & & 15,39 & \\
\hline дистальная часть & & & & & & \\
\hline отсутствует (0) & & 0,00 & & & 0,00 & \\
\hline слабое развитие (1) & 62 & 6,45 & 1,95 & 13 & 7,69 & 2,08 \\
\hline среднее развитие (2) & & 91,94 & & & 76,92 & \\
\hline сильное развитие (3) & & 1,61 & & & 15,39 & \\
\hline Наклон лба & & & & & & \\
\hline сильно покатый (1) & 55 & 0,00 & 235 & 13 & 0,00 & 262 \\
\hline средне покатый (2) & & 65,45 & 2,35 & 13 & 38,46 & 2,62 \\
\hline прямой (3) & & 34,55 & & & 61,54 & \\
\hline Развитие надбровья & & & & & & \\
\hline слабое развитие (1) & 58 & 84,48 & & & 100,00 & \\
\hline среднее развитие (2) & 58 & 15,52 & 1,16 & 13 & 0,00 & 1,00 \\
\hline сильное развитие (3) & & 0,00 & & & 0,00 & \\
\hline
\end{tabular}


НАРОДЫ МИРА: АРХЕОЛОГИЯ, АНТРОПОЛОГИЯ, ИСТОРИЯ

Продолжение таблицы 6

Continuation of table 6

\begin{tabular}{|c|c|c|c|c|c|c|}
\hline \multirow[b]{2}{*}{ Признаки } & \multirow[b]{2}{*}{$N$} & \multicolumn{2}{|c|}{ Мужчины } & \multirow[b]{2}{*}{$N$} & \multicolumn{2}{|c|}{ Женщины } \\
\hline & & $\begin{array}{c}\text { частота встре- } \\
\text { чаемости, \% }\end{array}$ & $\begin{array}{c}\text { средний } \\
\text { балл } \\
\end{array}$ & & $\begin{array}{c}\text { частота встре- } \\
\text { чаемости, \% }\end{array}$ & $\begin{array}{c}\text { средний } \\
\text { балл } \\
\end{array}$ \\
\hline Профиль лица & \multirow{4}{*}{62} & & \multirow{4}{*}{1,84} & \multirow{4}{*}{13} & & \multirow{4}{*}{1,31} \\
\hline плоское (1) & & 16,13 & & & 69,23 & \\
\hline среднее (2) & & 83,87 & & & 30,77 & \\
\hline узкое (3) & & 0,00 & & & 0,00 & \\
\hline Развитие скул & \multirow{4}{*}{62} & & \multirow{4}{*}{1,74} & \multirow{4}{*}{13} & & \multirow{4}{*}{2,15} \\
\hline слабое развитие (1) & & 27,42 & & & 0,00 & \\
\hline среднее развитие (2) & & 70,97 & & & 84,62 & \\
\hline сильное развитие (3) & & 1,61 & & & 15,38 & \\
\hline Выступание подбородка & \multirow{4}{*}{62} & & \multirow{4}{*}{1,34} & \multirow{4}{*}{13} & & \multirow{4}{*}{1,38} \\
\hline убегающий (1) & & 67,74 & & & 61,54 & \\
\hline прямой (2) & & 30,65 & & & 38,46 & \\
\hline выступающий (3) & & 1,61 & & & 0,00 & \\
\hline Высота переносья & \multirow{4}{*}{61} & & \multirow{4}{*}{1,49} & \multirow{4}{*}{13} & & \\
\hline низкое (1) & & 50,82 & & & 46,15 & \\
\hline среднее (2) & & 49,18 & & & 53,85 & 1,54 \\
\hline высокое (3) & & 0,00 & & & 0,00 & \\
\hline Поперечный профиль спинки носа & & & & & & \\
\hline плоский (1) & & 4,84 & & 13 & 15,38 & \\
\hline средний (2) & 62 & 95,16 & 1,95 & 13 & 84,62 & 1,85 \\
\hline заостренный (3) & & 0,00 & & & 0,00 & \\
\hline Костный профиль спинки носа & & & & & & \\
\hline вогнутый (1) & & 0,00 & & & 0,00 & \\
\hline прямой (2) & 62 & 95,16 & 2,05 & 13 & 100,00 & 2,00 \\
\hline выгнутый (3) & & 4,84 & & & 0,00 & \\
\hline Хрящевой профиль спинки носа & & & & & & \\
\hline вогнутый (1) & 62 & 3,23 & 107 & 13 & 0,00 & 200 \\
\hline прямой (2) & 62 & 96,77 & 1,91 & 13 & 100,00 & 2,00 \\
\hline выгнутый (3) & & 0,00 & & & 0,00 & \\
\hline Общзий профиль спинки носа & & & & & & \\
\hline вогнутый (1) & & 3,23 & & & 0,00 & \\
\hline прямой (2) & 62 & 91,93 & 2,02 & 13 & 100,00 & 2,00 \\
\hline выгнутый (3) & & 4,84 & & & 0,00 & \\
\hline извилистый (4) & & 0,00 & & & 0,00 & \\
\hline Положение основания носа & & & & & & \\
\hline приподнятое (1) & 62 & 56,45 & & 13 & 46,15 & \\
\hline горизонтальное (2) & 62 & 43,55 & 1,44 & 13 & 53,85 & 1,54 \\
\hline опущенное (3) & & 0,00 & & & 0,00 & \\
\hline Положение кончика носа & & & & & & \\
\hline приподнятое (1) & 62 & 6,45 & 194 & 13 & 7,69 & \\
\hline горизонтальное (2) & 62 & 93,55 & 1,94 & 13 & 92,31 & 1,92 \\
\hline опущенное (3) & & 0,00 & & & 0,00 & \\
\hline Высота крыльев носа & & & & & & \\
\hline низкая (1) & 62 & 4,84 & & 13 & 15,38 & 215 \\
\hline средняя (2) & 62 & 70,97 & 2,19 & 13 & 53,85 & 2,15 \\
\hline высокая (3) & & 24,19 & & & 30,77 & \\
\hline Выступание крыльев носа & & & & & & \\
\hline слабое (1) & 62 & 24,19 & & 13 & 23,08 & \\
\hline среднее (2) & 62 & 72,58 & 1,79 & 13 & 61,54 & 1,92 \\
\hline сильное (3) & & 3,23 & & & 15,38 & \\
\hline
\end{tabular}


Окончание таблищь 6

End of table 6

\begin{tabular}{|c|c|c|c|c|c|c|}
\hline \multirow[b]{2}{*}{ Признаки } & \multirow[b]{2}{*}{$N$} & \multicolumn{2}{|c|}{ Мужчины } & \multirow[b]{2}{*}{$N$} & \multicolumn{2}{|c|}{ Женщины } \\
\hline & & $\begin{array}{c}\text { частота встре- } \\
\text { чаемости, \% }\end{array}$ & $\begin{array}{c}\text { средний } \\
\text { балл } \\
\end{array}$ & & $\begin{array}{c}\text { частота встре- } \\
\text { чаемости, \% }\end{array}$ & $\begin{array}{c}\text { средний } \\
\text { балл } \\
\end{array}$ \\
\hline Высота верхней губы & \multirow{4}{*}{62} & & \multirow{4}{*}{1,94} & \multirow{4}{*}{13} & & \multirow{4}{*}{1,77} \\
\hline низкая (1) & & 6,45 & & & 23,08 & \\
\hline средняя (2) & & 93,55 & & & 76,92 & \\
\hline высокая (3) & & 0,00 & & & 0,00 & \\
\hline Профиль верхней губь & \multirow{4}{*}{62} & & \multirow{4}{*}{1,47} & \multirow{4}{*}{13} & & \multirow{4}{*}{1,08} \\
\hline прохейлия (1) & & 53,23 & & & 92,31 & \\
\hline ортохейлия (2) & & 46,77 & & & 7,69 & \\
\hline опистохейлия (3) & & 0,00 & & & 0,00 & \\
\hline Толщина верхней губы & \multirow{4}{*}{62} & & \multirow{4}{*}{1,73} & \multirow{4}{*}{13} & & \multirow{4}{*}{1,54} \\
\hline тонкая (1) & & 35,48 & & & 53,85 & \\
\hline средняя (2) & & 56,46 & & & 38,46 & \\
\hline толстая (3) & & 8,06 & & & 7,69 & \\
\hline Толщина нижней губы & \multirow{4}{*}{62} & & \multirow{4}{*}{2,03} & \multirow{4}{*}{13} & & \multirow{4}{*}{2,00} \\
\hline тонкая (1) & & 9,21 & & & 13,33 & \\
\hline средняя (2) & & 61,84 & & & 80,00 & \\
\hline толстая (3) & & 28,95 & & & 6,67 & \\
\hline
\end{tabular}

Таблица 7. Распределение оттенков кожи (по шкале Лушана) у минахасцев и сангирцев

Table 7. Distribution of skin tones (according to Von Luschan's chromatic scale) in the Minahasans and Sangirese

\begin{tabular}{|l|c|c|c|c|c|c|c|c|c|c|}
\hline Баллы & 9 & 10 & 11 & 12 & 13 & 14 & 15 & 16 & 17 & 18 \\
\hline $\begin{array}{l}\text { Частота встречаемо- } \\
\text { сти у минахасцев }\end{array}$ & 6,25 & 13,54 & 17,71 & 12,50 & 22,92 & 14,58 & 7,29 & 3,13 & 1,04 & 1,04 \\
\hline $\begin{array}{l}\text { Частота встречаемо- } \\
\text { сти у сангирцев }\end{array}$ & 2,63 & 2,63 & 10,53 & 9,21 & 26,32 & 25,00 & 7,89 & 6,58 & 7,89 & 1,32 \\
\hline$p$ & 0,2644 & 0,0127 & 0,1864 & 0,4952 & 0,6069 & 0,0866 & 0,8826 & 0,2877 & 0,0252 & 0,865 \\
\hline
\end{tabular}

\section{Таблица 8. Распределение цвета глаз (по шкале Бунака) у минахасцев и сангирцев}

Table 8. Distribution of eye colors (according to Bunak's scale) in the Minahasans and Sangirese

\begin{tabular}{|l|c|c|c|c|}
\hline Баллы & 1 & 2 & 3 & 5 \\
\hline $\begin{array}{l}\text { Частота встречаемо- } \\
\text { сти у минахасцев }\end{array}$ & 36,46 & 57,29 & 2,08 & 1,04 \\
\hline $\begin{array}{l}\text { Частота встречаемо- } \\
\text { сии у сангирцев }\end{array}$ & 52,63 & 47,37 & 0 & 0 \\
\hline$p$ & 0,0365 & 0,2005 & & \\
\hline
\end{tabular}

Таблица 9. Распределение формы волос у минахасцев и сангирцев

Table 9. Distribution of hair forms in the Minahasans and Sangirese

\begin{tabular}{|l|c|c|c|}
\hline Баллы & Прямые & Волнистые & Курчавые \\
\hline $\begin{array}{l}\text { Частота встречаемо- } \\
\text { сти у минахасцев }\end{array}$ & 96,88 & 3,13 & 0 \\
\hline $\begin{array}{l}\text { Частота встречаемо- } \\
\text { сти у сангирцев }\end{array}$ & 77,63 & 17,11 & 5,26 \\
\hline$p$ & 0,0001 & 0,002 & \\
\hline
\end{tabular}


НАРОДЫ МИРА: АРХЕОЛОГИЯ, АНТРОПОЛОГИЯ, ИСТОРИЯ

Таблица 10. Достоверность различий балловых признаков у минахасцев и сангирцев

Table 10. Significance of differences of trait scores in the Minahasans and Sangirese

\begin{tabular}{|c|c|c|c|c|c|c|c|c|c|}
\hline & 1 & 1 & & 2 & 2 & & 3 & 3 & \\
\hline Признаки & $\begin{array}{l}\text { мина- } \\
\text { хасцы }\end{array}$ & $\begin{array}{l}\text { сангир- } \\
\text { цы }\end{array}$ & $p$ & $\begin{array}{l}\text { мина- } \\
\text { хасцы }\end{array}$ & $\begin{array}{c}\text { сангир- } \\
\text { цы }\end{array}$ & $p$ & $\begin{array}{l}\text { мина- } \\
\text { хасцы }\end{array}$ & $\begin{array}{c}\text { сангир- } \\
\text { цы }\end{array}$ & $p$ \\
\hline Ширина глазной щели & 0,2632 & 0,2903 & 0,7235 & 0,7368 & 0,7097 & 0,7235 & 0,0000 & 0,0000 & \\
\hline Наклон глазной щели & 0,0000 & 0,0000 & & 0,9459 & 0,9516 & 0,8812 & 0,0541 & 0,0484 & 0,8812 \\
\hline Складка $p$ & 0,0526 & 0,0806 & 0,5086 & 0,8947 & 0,8871 & 0,8868 & 0,0526 & 0,0323 & 0,5618 \\
\hline Складка $m$ & 0,0526 & 0,0645 & 0,7664 & 0,7500 & 0,8710 & 0,0769 & 0,1974 & 0,0645 & 0,0258 \\
\hline Складка $d$ & 0,0526 & 0,0645 & 0,7664 & 0,8421 & 0,9194 & 0,1716 & 0,1579 & 0,0161 & 0,0053 \\
\hline Наклон лба & 0,0000 & 0,0000 & & 0,5676 & 0,6545 & 0,3220 & 0,4324 & 0,2923 & 0,3220 \\
\hline Надбровье & 0,7432 & 0,8448 & 0,1589 & 0,2568 & 0,1552 & 0,1589 & 0,0000 & 0,0000 & \\
\hline Профиль лица & 0,2667 & 0,1613 & 0,1399 & 0,7333 & 0,8387 & 0,1399 & 0,0000 & 0,0000 & \\
\hline Выступание скул & 0,1733 & 0,2742 & 0,1575 & 0,8267 & 0,7097 & 0,1056 & 0,0000 & 0,0161 & 0,2720 \\
\hline Выступание подбородка & 0,7467 & 0,6774 & 0,3725 & 0,2533 & 0,3065 & 0,4899 & 0,0000 & 0,0161 & 0,2720 \\
\hline Высота переносья & 0,5200 & 0,5000 & 0,8168 & 0,4800 & 0,4839 & 0,8168 & 0,0000 & 0,0000 & \\
\hline Поперечный профиль & 0,1333 & 0,0484 & 0,0937 & 0,8667 & 0,9516 & 0,0937 & 0,0000 & 0,0000 & \\
\hline $\begin{array}{l}\text { Костный профиль спинки } \\
\text { носа }\end{array}$ & 0,0000 & 0,0000 & & 0,9867 & 0,9516 & 0,2265 & 0,0133 & 0,0484 & 0,2265 \\
\hline $\begin{array}{l}\text { Хрящевой профиль спин- } \\
\text { ки носа }\end{array}$ & 0,0400 & 0,0323 & 0,8113 & 0,8533 & 0,9677 & $\mathbf{0 , 0 2 2 9}$ & 0,1067 & 0,0000 & 0,0090 \\
\hline $\begin{array}{l}\text { Общий профиль спинки } \\
\text { носа }\end{array}$ & 0,0400 & 0,0323 & 0,8113 & 0,8400 & 0,9194 & 0,1628 & 0,1200 & 0,0484 & 0,1424 \\
\hline Кончик носа & 0,0800 & 0,0645 & 0,7290 & 0,9200 & 0,9355 & 0,7290 & 0,0000 & 0,0000 & \\
\hline Основание носа & 0,6133 & 0,5645 & 0,5640 & 0,3867 & 0,4355 & 0,5640 & 0,0000 & 0,0000 & \\
\hline Высота крыльев носа & 0,1216 & 0,0484 & 0,1362 & 0,6351 & 0,7097 & 0,3588 & 0,2432 & 0,2419 & 0,9860 \\
\hline Выступание крыльев носа & 0,3108 & 0,2419 & 0,3741 & 0,6757 & 0,7258 & 0,5271 & 0,0135 & 0,0323 & 0,4586 \\
\hline Высота верхней губы & 0,1711 & 0,0645 & 0,0602 & 0,7763 & 0,9355 & 0,0106 & 0,0526 & 0,0000 & 0,0690 \\
\hline Профиль верхней губы & 0,6667 & 0,5323 & 0,1114 & 0,3333 & 0,4677 & 0,1114 & 0,0000 & 0,0000 & \\
\hline Толщина верхней губы & 0,3684 & 0,3548 & 0,8689 & 0,5789 & 0,5645 & 0,8661 & 0,0526 & 0,0806 & 0,5086 \\
\hline Толщина нижней губы & 0,0921 & 0,2097 & 0,0530 & 0,6184 & 0,5484 & 0,4076 & 0,2895 & 0,2419 & 0,5311 \\
\hline
\end{tabular}

Таблица 11. Достоверные различия признаков по результатам одномерного дисперсионного анализа антропологических признаков для мужчин минахасцев и сангирцев

Table 11. Significant differences in traits according to the results of one-dimensional analysis of variance of anthropological traits for Minahasan and Sangirese men

\begin{tabular}{|l|c|c|}
\hline \multicolumn{1}{|c|}{ Признаки } & $\begin{array}{c}F \text {-критерий } \\
\text { Фишера }\end{array}$ & $p$ \\
\hline Вес & 6,882 & 0,010 \\
\hline Цвет кожи & 9,030 & 0,030 \\
\hline Форма волос & 16,130 & 0,001 \\
\hline Рост бровей & 6,390 & 0,013 \\
\hline Цвет глаз & 7,006 & 0,009 \\
\hline $\begin{array}{l}\text { Дистальная часть } \\
\text { складки верхнего века }\end{array}$ & 5,478 & 0,021 \\
\hline
\end{tabular}




\section{СПИСОК ЛИТЕРАТУРЫ}

1. Бунак, В. В. Антропометрия / В. В. Бунак. М. : Учпедгиз, 1941. -365 с.

2. Рогинский, Я. Я. Антропология / Я. Я. Рогинский, М. Г. Левин. - М. : Высш. шк., 1963.-498 с.

3. Bean, R. B. The Benguet Igorots: a somatologic study of the live folk of Benguet and Lepanto-Bontoc / R. B. Bean // Philippine Journal of Science. - 1908. - Vol. III, № 6. - P. 413-472.

4. Bean, R. B. The racial anatomy of the Philippine Islanders: introducing new methods of anthropology and showing their application to the Filipinos with a classification of human ears and a scheme for the heredity of anatomical characters in man / R. B. Bean. Philadelphia : J.B. Lippincott Co, 1910. - 236 p.

5. Denisova admixture and the first modern human dispersals into Southeast Asia and Oceania / D. Reich, N. Patterson, M. Kircher [et al.] // The American Journal of Human Genetics. - 2011. Vol. 89. - P. 516-528.

6. Folkmar, D. Album of Philippine types: Christians and Moros. Eighty plates, representing thirty-seven provinces and islands / D. Folkmar. Manila : Bureau of Public Prtg., 1904. - 186 p.

7. Friederici, G. Wissenschaftliche Ergebnisse einer amtlichen Forschungsreise nach dem Bismarck-Archipel im Jahre 1908. Vol. II. Beitrüge Zur Volker- und Sprachenkunde von DeutschNeuguinea / G. Friederici. - Berlin : Ernst Siegfried Mittler und Sohn, 1912. $-324 \mathrm{p}$.

8. Ghosh, S. Understanding morphological changes from parental and filial generations: a case study of the Santhals of West Bengal / S. Ghosh, S. L. Malik // Indian Anthropologist. - 2009. - Vol. 39, № 1/2. - P. 99-116.

9. Hambruch, P. Beiträge zur Somatologie von Madagaskar, Indonesien, Bismarckarchipel und Mikronesien / P. Hambruch. - Berlin : Forschungsreise S. M. S. Planet, 1906-1907, 1909.-168 p.

10. Howells, W. W. Anthropometry and blood types in Fiji and the Solomon Islands / W. W. Howells // Anthropological Papers of the American Museum of Natural History. - 1933. - Vol. 33, part 4. - P. 279-339.

11. Hiroa, T. R. (Buck P. H.). Maori somatology. Racial Averages. Part 1 / T. R. Hiroa (P. H. Buck) // Journal of the Polynesian Society. - 1922. - Vol. 31, № 121. P. $37-44$.

12. Hiroa, T. R. (Buck P. H.). Maori somatology. Racial Averages. Part 2 / T. R. Hiroa (P. H. Buck) // Journal of the Polynesian Society. - 1922. - Vol. 31, № 123. - P. 145-153.

13. Hiroa, T. R. (Buck P. H.). Maori somatology. Racial Averages. Part 3 / T. R. Hiroa (P. H. Buck) // Journal of the Polynesian Society. - 1922. - Vol. 31, № 124. - P. 159-710.
14. Hiroa, T. R. (Buck P. H.). Maori somatology. Racial averages. Part 4 / T. R. Hiroa (P. H. Buck)// Journal of the Polynesian Society. - 1922. - Vol. 32, № 125. P. 21-28.

15. Hiroa, T. R. (Buck P. H.). Maori somatology. Racial Averages. Part 5/ T. R. Hiroa (P. H. Buck) // Journal of the Polynesian Society. - 1923. - Vol. 32, № 128. P. 189-199.

16. Humphreys, C. B. The southern New Hebrides: an ethnological record / C. B. Humphreys. CUP Archive, The University Press, 1926. - 214 p.

17. Kurisu, K. Multivariate statistical analysis on the physical interrelationship of native tribes in Sarawak, Malaysia / K. Kurisu // American Journal of Physical Anthropology. - 1970. - Vol. 33. - P. 229-234.

18. Lee, H. J. Comparison of Korean and Japanese head and face anthropometric characteristics / H. J. Lee, S. J. Park // Human Biology. - 2008. - Vol. 80 (3). P. 313-330.

19. Physical characteristics of Chinese Hakka / L. Zheng, Y. Li, S. Lu [et al.] // Science China Life Sciences. - 2013. - Vol. 56 (6). - P. 541-551.

20. Reed, W. A. Negritos of Zambales/W.A. Reed. Manila : Bureau of Public Printing, 1904. - 89 p.

21. Rodenwaldt, E. Die Mestizen auf Kisar. Vol. 2 / E. Rodenwaldt. - Batavia : G. Fisher, 1927. - 483 p. 22. Sarasin, P. Versuch einer Anthropologie der Insel Celebes / P. Sarasin. - Wiesbaden : C.W. Kreidel, 1905. $-82 \mathrm{p}$.

23. Sarasin, P. Anthropologie der Neu Caledonier und Loyalty Insulaner / P. Sarasin. - Berlin : C.W. Kreidel, 1916-1922. - $521 \mathrm{p}$.

24. Schlaginhaufen, O. Zur Anthropologie der Mikronesischen Inselgruppe Kapingamarangi (Greenwich-Inseln)/ O. Schlaginhaufen. - Zürich : Orell Füssli, 1929. - 287 p.

25. Shapiro, H. L. The physical characters of the Society Islanders / H. L. Shapiro// Memoirs of the Bernice P. Bishop Museum, 1930. - Vol. XI, № 4. - P. 1-39.

26. Shapiro, H. L. The physical characteristics of the Ontong Javanese: a contribution to the study of the non-Melanesian elements in Melanesia / H. L. Shapiro // Anthropological Papers of the American Museum of Natural History. - 1933. - Vol. XXXIII, part III. P. 227-278.

27. Shapiro, H. L. The anthropometry of Pukapuka based upon data collected by Ernest and Pearl Beaglehole / H. L. Shapiro // Anthropological Papers of the American Museum of Natural History. - 1942. Vol. XXXVIII, part III. - P. 1-169.

28. Sneddon, J. N. Proto-Sangiric and the Sangiric languages / J. N. Sneddon // Pacific Linguistics. 1984. - Ser. B. - № 91. - 5 p.

29. Sullivan, L. R. A contribution to Samoan somatology / L. R. Sullivan // Memoirs of the Bernice P. Bishop Museum. - 1921. - Vol. 8, № 2. - P. 1-26. 
30. Sullivan, L. R. A contribution to Tongan somatology / L. R. Sullivan // Memoirs of the Bernice P. Bishop Museum. - 1922. - Vol. 8, № 4. - P. 1-34.

31. Sullivan, L. R. Marquesan somatology with comparative notes on Samoa and Tonga / L. R. Sullivan. Honolulu: Hawaii, Bishop Museum Press, 1923. - 111 p.

32. Sullivan, L. R. Observations on Hawaiian somatology / L. R. Sullivan, C. Wissler // Memoirs of the Bernice P. Bishop Museum. - 1927. - Vol. 9, № 4. P. $1-343$.

33. Wagenseil, F. Anthropologische Untersuchung ostmalayischer Negrito / F. Wagenseil // Zeitschrift für Morphologie und Anthropologie. - 1967. - Vol. 59 (1). P. $1-25$.

34. Wigboldus, J. S. J. A history of the Minahasa c. 1615-1680 / J. S. J. Wigboldus // Archipel. - 1987. Vol. 34. - P. 63-101.

35. Wirz, P. Anthropologische und Ethnologische ergebnisse der Central Neu-Guinea Expedition 19211922 / P. Wirz // Nova Guinea. - 1924. - Vol. XVI. S. $59 .-148 \mathrm{p}$.

\section{REFERENCES}

1. Bunak V.V. Antropometriya [Anthropometry]. Moscow, Uchpedgiz, 1941. 365 p.

2. Roginskiy Ya.Ya., Levin M.G. Antropologya [Anthropology]. Moscow, Vysshaya Shkola Publ., $1963.498 \mathrm{p}$.

3. Bean R.B. The Benguet Igorots: A Somatologic Study of the Live Folk of Benguet and Lepanto-Bontoc. Philippine Journal of Science, 1908, vol. III, no. 6, pp. 413-472.

4. Bean R.B. The Racial Anatomy of the Philippine Islanders: Introducing New Methods of Anthropology and Showing Their Application to the Filipinos with a Classification of Human Ears and a Scheme for the Heredity of Anatomical Characters in Man. Philadelphia, J.B. Lippincott Co, 1910.236 p.

5. Reich D., Patterson N., Kircher M., Delfin F., Nandineni M.R., Pugach I., Ko A.M.-Sh., Ko Y.-Ch., Jinam T.A., Phipps M.E., Saitou N., Wollstein A., Kayser M., Paabo S., Stoneking M. Denisova Admixture and the First Modern Human Dispersals into Southeast Asia and Oceania. The American Journal of Human Genetics, 2011, vol. 89, pp. 516-528.

6. Folkmar D. Album of Philippine Types: Christians and Moros. Eighty Plates, Representing Thirty-Seven Provinces and Islands. Manila, Bureau of Public Prtg., 1904. 186 p.

7. Friederici G. Wissenschaftliche Ergebnisse einer amtlichen Forschungsreise nach dem BismarckArchipel im Jahre 1908. Vol. II Beitrüge Zur Volkerund Sprachenkunde von Deutsch-Neuguinea. Berlin, Ernst Siegfried Mittler und Sohn, 1912.324 S.
8. Ghosh S., Malik S.L. Understanding Morphological Changes from Parental and Filial Generations: A Case Study of the Santhals of West Bengal. Indian Anthropologist, 2009, vol. 39, no. 1/2, pp. 99-116.

9. Hambruch P. Beiträge zur Somatologie von Madagaskar, Indonesien, Bismarckarchipel und Mikronesien. Berlin, Forschungsreise S. M. S. Planet, 1906-1907, 1909.168 S.

10. Howells W.W. Anthropometry and Blood Types in Fiji and the Solomon Islands. Anthropological Papers of the American Museum of Natural History, 1933, vol. 33, part 4, pp. 279-339.

11. Hiroa T.R. (Buck P.H.) Maori Somatology. Racial Averages. Part 1. Journal of the Polynesian Society, 1922, vol. 31, no. 121, pp. 37-44.

12. Hiroa T.R. (Buck P.H.) Maori Somatology. Racial Averages. Part 2. Journal of the Polynesian Society, 1922, vol. 31, no. 123, pp. 145-153.

13. Hiroa T.R. (Buck P.H.) Maori Somatology. Racial Averages. Part 3. Journal of the Polynesian Society, 1922, vol. 31, no. 124, pp. 159-710.

14. Hiroa T.R. (Buck P.H.) Maori Somatology. Racial Averages. Part 4. Journal of the Polynesian Society, 1922, vol. 32, no. 125, pp. 21-28.

15. Hiroa T.R. (Buck P.H.) Maori Somatology. Racial Averages. Part 5. Journal of the Polynesian Society, 1923, vol. 32, no. 128, pp. 189-199.

16. Humphreys C.B. The Southern New Hebrides: An Ethnological Record. CUP Archive, The University Press, $1926.214 \mathrm{p}$.

17. Kurisu K. Multivariate Statistical Analysis on the Physical Interrelationship of Native Tribes in Sarawak, Malaysia. American Journal of Physical Anthropology, 1970, vol. 33, pp. 229-234.

18. Lee H.J., Park S.J. Comparison of Korean and Japanese Head and Face Anthropometric Characteristics. Human Biology, 2008, vol. 80 (3), pp. 313-330.

19. Zheng L., LiY., Lu S., Bao J., Wang Y., Zhang X., Xue H., Rong W. Physical Characteristics of Chinese Hakka. Science China Life Sciences, 2013, vol. 56 (6), pp. 541-551.

20. Reed W.A. Negritos of Zambales. Manila, Bureau of Public Printing, 1904. 89 p.

21. Rodenwaldt E. Die Mestizen auf Kisar. Vol. 2. Batavia, G. Fisher, 1927. 483 p.

22. Sarasin P. Versuch einer Anthropologie der Insel Celebes. Wiesbaden, C.W. Kreidel, 1905. 82 S.

23. Sarasin P. Anthropologie der Neu Caledonier und Loyalty Insulaner. Berlin, C.W. Kreidel, 1916-1922. $521 \mathrm{~S}$.

24. Schlaginhaufen O. Zur Anthropologie der Mikronesischen Inselgruppe Kapingamarangi (Greenwich-Inseln). Zürich, Orell Füssli, 1929. $287 \mathrm{~S}$. 
25. Shapiro H.L. The Physical Characters of the Society Islanders. Memoirs of the Bernice P. Bishop Museum, 1930, vol. XI, no. 4, pp. 1-39.

26. Shapiro H.L. The Physical Characteristics of the Ontong Javanese: A Contribution to the Study of the Non-Melanesian Elements in Melanesia. Anthropological Papers of the American Museum of Natural History, 1933, vol. XXXIII, part III, pp. 227-278.

27. Shapiro H.L. The Anthropometry of Pukapuka Based Upon Data Collected by Ernest and Pearl Beaglehole. Anthropological Papers of the American Museum of Natural History, 1942, vol. XXXVIII, part III, pp. 1-169.

28. Sneddon J.N. Proto-Sangiric and the Sangiric Languages. Pacific Linguistics, 1984, ser. B, no. 91.5 p.

29. Sullivan L.R. A Contribution to Samoan Somatology. Memoirs of the Bernice P. Bishop Museum, 1921, vol. 8, no. 2, pp. 1-26.
30. Sullivan L.R. A Contribution to Tongan Somatology. Memoirs of the Bernice P. Bishop Museum, 1922, vol. 8, no. 4, pp. 1-34.

31. Sullivan L.R. Marquesan Somatology with Comparative Notes on Samoa and Tonga. Honolulu, Hawaii, Bishop Museum Press, 1923. 111 p.

32. Sullivan L.R., Wissler C. Observations on Hawaiian Somatology. Memoirs of the Bernice P. Bishop Museum, 1927, vol. 9, no. 4, pp. 1-343.

33. Wagenseil F. Anthropologische Untersuchung ostmalayischer Negrito. Zeitschrift für Morphologie und Anthropologie, 1967, vol. 59 (1), S. 1-25.

34. Wigboldus J.S.J. A History of the Minahasa c. 1615-1680. Archipel, 1987, vol. 34, pp. 63-101.

35. Wirz P. Anthropologische und Ethnologische ergebnisse der Central Neu-Guinea Expedition 19211922. Nova Guinea, 1924, vol. XVI, S. 59. 148 S.

\section{Information About the Authors}

Stanislav V. Drobyshevsky, Candidate of Sciences (Biology), Associate Professor, Department of Anthropology, Lomonosov Moscow State University, Leninskie Gory, 1, Bld. 12, 119234 Moscow, Russian Federation, dsv_anth@mail.ru, https://orcid.org/0000-0003-3099-9962

Ekaterina M. Selivanova, Postgraduate Student, Department of Anthropology, Lomonosov Moscow State University, Leninskie Gory, 1, Bld. 12, 119234 Moscow, Russian Federation, selivanova.e.m@gmail.com, https://orcid.org/0000-0002-3311-6611

Marina A. Negasheva, Doctor of Sciences (Biology), Professor, Department of Anthropology, Lomonosov Moscow State University, Leninskie Gory, 1, Bld. 12, 119234 Moscow, Russian Federation, negasheva@mail.ru, https://orcid.org/0000-0002-7572-4316

\section{Информация об авторах}

Станислав Владимирович Дробышевский, кандидат биологических наук, доцент кафедры антропологии, Московский государственный университет им. М.В. Ломоносова, Ленинские горы, 1, стр. 12, 119234 г. Москва, Российская Федерация, dsv_anth@mail.ru, https://orcid.org/0000-0003-3099-9962

Екатерина Максимовна Селиванова, аспирантка кафедры антропологии, Московский государственный университет им. М.В. Ломоносова, Ленинские горы, 1, стр. 12, 119234 г. Москва, Российская Федерация, selivanova.e.m@gmail.com, https://orcid.org/0000-0002-3311-6611

Марина Анатольевна Негашева, доктор биологических наук, профессор кафедры антропологии, Московский государственный университет им. М.В. Ломоносова, Ленинские горы, 1 , стр. 12, 119234 г. Москва, Российская Федерация, negasheva@mail.ru, https://orcid.org/0000-0002-7572-4316 